\title{
The Effect of N, P, K Fertilizer and Nano Silica Fertilizer to Total N Content, N Uptake, and Black Rice Yield (Oryza sativa L. Indica) on Inceptisols from Jatinangor
}

\author{
Nabilla Salsa Amalya*, Anni Yuniarti, Ade Setiawan, Yuliati Machfud \\ Department of Soil Science, Faculty of Agriculture, Universitas Padjadjaran, Bandung, Indonesia \\ Email address: \\ nabillasamalya@gmail.com (N. S. Amalya), anni_yuniarti@yahoo.com (A. Yuniarti), de_setiawan@yahoo.com (A. Setiawan), \\ yuliatimach@yahoo.com (Y. Machfud) \\ *Corresponding author
}

\section{To cite this article:}

Nabilla Salsa Amalya, Anni Yuniarti, Ade Setiawan, Yuliati Machfud. The Effect of N, P, K Fertilizer and Nano Silica Fertilizer to Total N Content, N Uptake, and Black Rice Yield (Oryza sativa L. Indica) on Inceptisols from Jatinangor. Journal of Plant Sciences.

Vol. 8, No. 5, 2020, pp. 185-188. doi: 10.11648/j.jps.20200805.21

Received: April 3, 2020; Accepted: April 20, 2020; Published: October 26, 2020

\begin{abstract}
Black rice is a functional food with high anthocyanin content that can be beneficial for health. Inceptisols have the potential to support the growth of black rice plants because it is widely distributed in the mainland region of Indonesia, which is around 70.52 million ha. However, it has problems with its relatively low soil fertility, especially in the nutrient content of N. These problems need to be sought with proper handling, one of which is by fertilizing using N, P, K fertilizer and Nano Silica fertilizer. This study aims to determine the effect of N, P, K fertilizer and Nano Silica fertilizer on total N content, N uptake, and Black Rice Yield (Oryza sativa L. indica) on Inceptisols from Jatinangor. This research was conducted in September 2019 until January 2020 in the Ciparanje Experiment Garden, Faculty of Agriculture, Padjadjaran University, Jatinangor, Sumedang, West Java, with an altitude of 750 meters above sea level. The experimental design was carried out using a Randomized Block Design (RBD) consisting of nine treatments with three replications. The results showed that the combination of $1 \mathrm{~N}, \mathrm{P}, \mathrm{K}$ fertilizer (Urea $300 \mathrm{~kg} \mathrm{ha}^{-1}, \mathrm{SP}-3650 \mathrm{~kg} \mathrm{ha}^{-1}$, and $\left.\mathrm{KCl} 50 \mathrm{~kg} \mathrm{ha}^{-1}\right)$ followed by giving of 1 Nano Silica fertilizer $(2 \mathrm{~mL} / \mathrm{L})$ gives the best black rice yield with Dry Grain weight of $82.20 \mathrm{~g} /$ plant or equivalent to $11.18 \mathrm{t} \mathrm{ha}^{-1}$.
\end{abstract}

Keywords: Anthocyanin, Inceptisols, Synthesis Fertilizer, Nano Silica Fertilizer, Black Rice

\section{Introduction}

Black rice (Oryza sativa L. indica) is a functional food that has anthocyanin content that is indicated by the presence of thick red-blue-purple-purple pericarp. The content of anthocyanin in black rice is around $200-400 \mathrm{mg} 100 \mathrm{~g}^{-1}$ greater than red rice which is only $0.33-1.39 \mathrm{mg} 100 \mathrm{~g}^{-1}$ and black sticky rice around 109.52-256.61 mg $100 \mathrm{~g}^{-1}$ [1]. High anthocyanin content can help maintain balance in organ systems and hormones, cleanse toxins from the body (detoxification), reduce blood sugar levels, and be able to prevent cardiovascular diseases such as coronary heart disease and hypertension [2].

Black rice cultivation among Indonesian farmers is classified as not optimal and also rare. That is because of low productivity, long harvest life, and high stems making it susceptible to cracking [3], even though black rice has the potential to be developed in
Indonesia because it is one of the genetic sources of black rice with a considerable amount of 42 varieties [4]. The black rice plant used in this study is the local black rice Cianjur commonly used by farmers in Padaherang Village in Pangandaran District by providing liquid organic fertilizer derived from rabbit urine to optimize yields that can reach $4.29 \mathrm{tha}^{-1}$.

One of the lands that have the potential to support the growth of rice plants in the soil with the order of Inceptisols which is one of the most widespread land orders in Indonesia, around 70.52 million ha or $37.5 \%$ of the land area of Indonesia [5]. The problem that is often found in Inceptisols is the relatively low level of soil fertility, but can still be sought with appropriate handling and technology, one of which is fertilization [6].

Fertilizers used in this research are N (urea), P (SP-36), K (KCl) and liquid silica fertilizers that play a role in improving soil fertility to support growth and optimal crop yields, as well as to 
replace nutrients lost due to the leaching and harvesting process so that plant nutrient needs are still met [7]. The nutrient which is rarely seldom given into the soil in the cultivation of Gramineae plants, one of which is rice, $\mathrm{Si}$, so that the fulfillment of its needs only relies on availability in nature [8].

The Si element can increase soil $\mathrm{pH}$ due to the exchange of anions between $\mathrm{OH}^{-}$ions which are bound to $\mathrm{Al}$ and $\mathrm{Fe}$ with silicate ions so that released $\mathrm{OH}^{-}$ions can increase the $\mathrm{pH}$ of soil solution, strengthen plant tissue, so it is more resistant to pests and diseases and overcome drought water [9]. Nano silica technology is one of the uses and manufacture of material at a minimal size. Rice plants have a larger tissue scale of about $10-20 \mu$, compared to the nanoscale $\left(10^{-9} \mathrm{~m}\right)$, making it easier for nano-silica fertilizer to enter the rice plant tissue [10].

Application of liquid fertilizer enriched with $\mathrm{Si}$ concentration of $0.25-1 \%$ and $100 \%$ dose of $\mathrm{N}, \mathrm{P}, \mathrm{K}$ recommendations can increase the average absorption of $\mathrm{Si}$ by plants by $18.67-38.29 \%$ compared to only giving a dose of $100 \% \mathrm{~N}, \mathrm{P}, \mathrm{K}$ recommendation [11]. Giving liquid silica at a dose of $1 \mathrm{~L} /$ ha can give the best effect on leaf angle $\left(31.38^{\circ}\right)$, flag leaf angle $\left(18.75^{\circ}\right)$, plant dry weight $(40.67 \mathrm{~g})$, grain weight per clump $(57,77 \mathrm{~g})$, and 1000 grain weight $(22.48 \mathrm{~g})$ in rice plants [12].

The objective of this research was to investigate the effect of N, P, K and Nano Silica fertilizer applications on total N content, $\mathrm{N}$ uptake, and yield of black rice (Oryza sativa L. indica) on Inceptisols from Jatinangor.

\section{Materials and Methods}

\subsection{Site Description}

A field experiment was conducted in September 2019 to January 2020 at the Ciparanje Experiment Garden, Faculty of Agriculture, Universitas Padjadjaran. The elevation of the area is approximately $750 \mathrm{~m}$ above sea level. Initial soil analysis results showed that the characteristics of Inceptisols in the experimental field included $\mathrm{pH}$ 6.9, C-Organic 2.33\%, total $\mathrm{N} 0.18 \%$, and $\mathrm{C} / \mathrm{N} 13$.

\subsection{Experimental Design}

The study arranged in a Randomized Block Design consisted of 9 treatments and 3 replicates. The size of the planting distance used is $25 \mathrm{~cm} \times 25 \mathrm{~cm}$ with the number of one seed for one planting hole.

The treatments were are followed: $\mathrm{A}=$ Control (without $\mathrm{N}, \mathrm{P}$, K fertilizer and without Nano Silica); B $=1 \mathrm{~N}, \mathrm{P}, \mathrm{K}$ without Nano Silica; C $=1 \mathrm{~N}, \mathrm{P}, \mathrm{K}+1 / 2$ Nano Silica; D $=1 \mathrm{~N}, \mathrm{P}, \mathrm{K}+1 \mathrm{Nano}$ Silica; $E=1 \mathrm{~N}, \mathrm{P}, \mathrm{K}+1 \frac{1}{2}$ Nano Silica; $F=3 / 4 \mathrm{~N}, \mathrm{P}, \mathrm{K}+1 / 2 \mathrm{Nano}$ Silica; $G=3 / 4$ N, P, K + 1 Nano Silica; $H=3 / 4 N, P, K+1$ 1 1/2 Nano Silica; I = Habits of Black Rice Farmers (used liquid organic fertilizer from rabbit urine). The treatment I (Habits of Black
Rice Farmers) in this study was used as a comparison to see how much the difference in yield compared to the treatment given $\mathrm{N}$, $\mathrm{P}, \mathrm{K}$ and Nano Silica fertilizers.

The recommended dosage of inorganic fertilizer used in this study was $300 \mathrm{~kg} \mathrm{ha}^{-1}$ urea, $50 \mathrm{~kg} \mathrm{ha}^{-1} \mathrm{SP}-36$, and $50 \mathrm{~kg} \mathrm{ha}^{-1} \mathrm{KCl}$. Urea fertilizer had given 3 times at 7,21 and 42 days after planting with $1 / 3$ dose in each application. Phosphate (SP-36) and Potassium $(\mathrm{KCl})$ fertilizers had given once in 7 days after planting.

Nano Silica fertilizer had given as many as 4 times application with dipped into the roots of plants before transplanting and at 21,35 , and 49 days after planting by spraying the leaves of plants at a dose of $1 \mathrm{~L} \mathrm{ha}^{-1}$ (3.67 $\mathrm{mL} /$ plant). Organic fertilizer in the form of compost is used as basic fertilizer with a dose of $10 \mathrm{t} \mathrm{ha}^{-1}$ ( $74 \mathrm{~g} /$ plant) given once at the beginning of planting. Liquid organic fertilizer from rabbit urine given by spraying it into the leaves of the plant as much 7 times on intervals of 10 days application with a dose of $7 \mathrm{~L} \mathrm{ha}^{-1}(1.85 \mathrm{~mL} /$ plant$)$.

\subsection{Soil and Plant Sampling and Analysis}

Soil sampling for total $\mathrm{N}$ content analysis was carried out during the maximum vegetative phase at 78 days after planting by taking soil around plant roots, then drained, homogenized, and mashed. The fine soil samples are then filtered and further analyzed in the laboratory by the parameters to be tested. Plant sampling for $\mathrm{N}$ uptake analysis was carried out in the vegetative phase taken by cutting the whole stover of rice plants which were then cut into small pieces, dried and mashed for further analysis in the laboratory. Total $\mathrm{N}$-soil content and $\mathrm{N}$ uptake of plants were analyzed using the Kjeldahl method. Black rice was harvested 110 days after planting and counted Dry Harvest Grain Weights and Milled Dry Grain Weights.

\subsection{Data Analysis}

Observation data were analyzed using the SPSS version 16 software package with an $\mathrm{F}$ test at a 5\% level, and if there were significant differences in average treatment, the test was continued with Duncan's multiple range test (DMRT) at 5\% significance level. The parameters observed consisted of total $\mathrm{N}$ content, $\mathrm{N}$ uptake, and Black Rice Yield (Oryza sativa L. indica).

\section{Result and Discussion}

\subsection{Total N Content}

The application of N, P, K and Nano silica fertilizers affect the total $\mathrm{N}$ content soil in Inceptisols from Jatinangor. The effect of each treatment is presented in Table 1. The results show that the total $\mathrm{N}$-soil content after application of $\mathrm{N}, \mathrm{P}, \mathrm{K}$ and Nano silica fertilizers ranged from 0.16 to $0.26 \%$.

Table 1. Application N, P, K+ Nano Silica on Total N-soil Content.

\begin{tabular}{lll}
\hline Code & Treatments & Total N Content (\%) \\
\hline A & Control & $0,16 \mathrm{a}$ \\
B & 1 N, P, K without Nano Silica & $0,23 \mathrm{cde}$ \\
\hline
\end{tabular}




\begin{tabular}{lll}
\hline Code & Treatments & Total N Content (\%) \\
\hline C & $1 \mathrm{~N}, \mathrm{P}, \mathrm{K}+1 / 2$ Nano Silica & $0,23 \mathrm{cde}$ \\
$\mathrm{D}$ & $1 \mathrm{~N}, \mathrm{P}, \mathrm{K}+1$ Nano Silica & $0,26 \mathrm{e}$ \\
$\mathrm{E}$ & $1 \mathrm{~N}, \mathrm{P}, \mathrm{K}+11 / 2$ Nano Silica & $0,24 \mathrm{de}$ \\
$\mathrm{F}$ & $3 / 4 \mathrm{~N}, \mathrm{P}, \mathrm{K}+1 / 2$ Nano Silica & $0,20 \mathrm{bc}$ \\
$\mathrm{G}$ & $3 / 4 \mathrm{~N}, \mathrm{P}, \mathrm{K}+1$ Nano Silica & $0,20 \mathrm{bc}$ \\
$\mathrm{H}$ & $3 / 4 \mathrm{~N}, \mathrm{P}, \mathrm{K}+11 / 2$ Nano Silica & $0,21 \mathrm{bcd}$ \\
$\mathrm{I}$ & Habits of Black Rice Farmers & $0,18 \mathrm{ab}$ \\
\hline
\end{tabular}

Note: The numbers followed by the same letters in each column are not significantly different according to Duncan's Multiple Range Test at $5 \%$ level.

Based on Duncan's Multiple Range Test results with a 5\% significance level in Table 1 shows that treatment D (1 N, P, K +1 Nano Silica) has the highest $\mathrm{N}$-total soil content compared to other treatments, but not significantly different from treatment B (1 N, P, K and without Nano Silica), C (1 N, P, K + $1 / 2$ Nano Silica), and E ( $1 \mathrm{~N}, \mathrm{P}, \mathrm{K}+1 \frac{1 / 2}{2}$ Nano Silica). This is because the application of high doses of $\mathrm{N}$ fertilizer can infiltrate the soil in large quantities, resulting in the availability of $\mathrm{N}$-total in the soil and higher nutrient uptake of nitrogen in plants [13].

The application of $\mathrm{N}$ fertilizer, especially urea fertilizer, can cause the total $\mathrm{N}$ available in the soil to increase. Increased $\mathrm{N}$-total in the soil is an indicator of the availability of $\mathrm{N}$ nutrients. The availability of $\mathrm{N}$ nutrients in the soil is then transplanted to the roots and absorbed by plants [14].

The application of Nano Silica fertilizer given through leaves on black rice plants is thought to not have a significant effect in increasing the total N-soil because there is little chance that the Si element will fall to the ground so that Si has not fully dissolved in the soil. The application of Si fertilizer had no significant effect on the chemical properties of the soil in lowland rice plants [15].

\subsection{N Uptake}

The results of the analysis of variance show that the application of N, P, K fertilizer and Nano Silica fertilizer affect the $\mathrm{N}$ uptake of black rice plants presented in Table 2 .

Table 2. Application N, P, K+ Nano Silica on N Uptake.

\begin{tabular}{lll}
\hline Code & Treatments & N Uptake (g/plant) \\
\hline A & Control & $0,68 \mathrm{a}$ \\
B & $1 \mathrm{~N}, \mathrm{P}, \mathrm{K}$ without Nano Silica & $1,60 \mathrm{~b}$ \\
$\mathrm{C}$ & $1 \mathrm{~N}, \mathrm{P}, \mathrm{K}+1 / 2$ Nano Silica & $1,76 \mathrm{c}$ \\
$\mathrm{D}$ & $1 \mathrm{~N}, \mathrm{P}, \mathrm{K}+1$ Nano Silica & $2,03 \mathrm{~d}$ \\
$\mathrm{E}$ & $1 \mathrm{~N}, \mathrm{P}, \mathrm{K}+1 \mathrm{1} / 2$ Nano Silica & $1,85 \mathrm{c}$ \\
$\mathrm{F}$ & $3 / 4 \mathrm{~N}, \mathrm{P}, \mathrm{K}+1 / 2$ Nano Silica & $1,51 \mathrm{~b}$ \\
$\mathrm{G}$ & $3 / 4 \mathrm{~N}, \mathrm{P}, \mathrm{K}+1$ Nano Silica & $1,50 \mathrm{~b}$ \\
$\mathrm{H}$ & $3 / 4 \mathrm{~N}, \mathrm{P}, \mathrm{K}+11 / 2$ Nano Silica & $1,52 \mathrm{~b}$ \\
I & Habits of Black Rice Farmers & $0,73 \mathrm{a}$ \\
\hline
\end{tabular}

Note: The numbers followed by the same letters in each column are not significantly different according to Duncan's Multiple Range Test at 5\% level.

Table 2 shows the $\mathrm{N}$ uptake in treatment $\mathrm{D}(1 \mathrm{~N}, \mathrm{P}, \mathrm{K}+1$ Nano Silica) has the highest $\mathrm{N}$ uptake value and is significantly different from other treatments that are equal to $2.03 \mathrm{~g}$ /plant. Plant $\mathrm{N}$ uptake is determined by $\mathrm{NO}_{3}{ }^{-}$and $\mathrm{NH}_{4}{ }^{+}$ whose supply is influenced by the availability of $\mathrm{N}$-total soil. The amount of $\mathrm{N}$-total that increases with increasing $\mathrm{N}$ fertilizer application does not always cause the supply of $\mathrm{NO}_{3}^{-}$ and $\mathrm{NH}_{4}{ }^{+}$to be available to plants. This is thought to be due to the nature of the $\mathrm{N}$ element, which is easily washed and evaporated [16].

The application of silica in plants will accumulate in the leaves of rice, which serves to keep the leaves upright so that it can help the optimal absorption of sunlight. The resulting photosynthate will be used for the growth process, namely elongation of the stem. Silica in plants can also cause roots to grow well, so that nutrient absorption becomes more intensive [17].

\subsection{The Yield of Black Rice}

The yield component measured in this study is the weight of the Harvested Dry Grain (HDG) and Milled Dry Grain (MDG). The results show that the $\mathrm{D}$ treatments $(1 \mathrm{~N}, \mathrm{P}, \mathrm{K}+1 \mathrm{Nano}$ Silica) had the highest results and were significantly different from the other treatments (Table 3 ).

Table 3. Application N, P, K+ Nano Silica on the Yield of Black Rice.

\begin{tabular}{llll}
\hline Code & Treatments & HDG (g/plant) & MDG (g/plant) \\
\hline A & Control & $34,00 \mathrm{a}$ & $27,00 \mathrm{a}$ \\
B & $1 \mathrm{~N}, \mathrm{P}, \mathrm{K}$ without Nano Silica & $77,77 \mathrm{c}$ & $71,10 \mathrm{c}$ \\
$\mathrm{C}$ & $1 \mathrm{~N}, \mathrm{P}, \mathrm{K}+1 / 2$ Nano Silica & $81,90 \mathrm{c}$ & $74,57 \mathrm{~cd}$ \\
$\mathrm{D}$ & $1 \mathrm{~N}, \mathrm{P}, \mathrm{K}+1$ Nano Silica & $88,80 \mathrm{~d}$ & $82,20 \mathrm{e}$ \\
$\mathrm{E}$ & $1 \mathrm{~N}, \mathrm{P}, \mathrm{K}+11 \mathrm{1} / 2$ Nano Silica & $81,63 \mathrm{c}$ & $75,07 \mathrm{~d}$ \\
$\mathrm{~F}$ & $3 / 4 \mathrm{~N}, \mathrm{P}, \mathrm{K}+1 / 2$ Nano Silica & $79,67 \mathrm{c}$ & $72,37 \mathrm{~cd}$ \\
$\mathrm{G}$ & $3 / 4 \mathrm{~N}, \mathrm{P}, \mathrm{K}+1$ Nano Silica & $78,57 \mathrm{c}$ & $71,20 \mathrm{c}$ \\
$\mathrm{H}$ & $3 / 4 \mathrm{~N}, \mathrm{P}, \mathrm{K}+11 / 2$ Nano Silica & $79,77 \mathrm{c}$ & $72,80 \mathrm{~cd}$ \\
I & Habits of Black Rice Farmers & $44,43 \mathrm{~b}$ & $37,37 \mathrm{~b}$ \\
\hline
\end{tabular}

Note: The numbers followed by the same letters in each column are not significantly different according to Duncan's Multiple Range Test at 5\% level.

Table 3 shows the weight of Harvested Dry Grain (HDG) in treatment $\mathrm{D}$ that is $88.80 \mathrm{~g} /$ plant and the weight of the Milled Dry Grain in treatment $\mathrm{D}$ that is $82.20 \mathrm{~g} /$ plant or equivalent to $11.18 \mathrm{tha}^{-1}$. The provision of sufficient $\mathrm{N}$ in the generative phase is essential in slowing the aging process of leaves so that it can maintain photosynthesis during the grain filling phase and increase in protein in grain [18]. The growth of rice plant biomass is affected by the presence of sufficient nutrients $\mathrm{N}$ and $\mathrm{P}[19]$.

The application of silica can play a role in increasing the efficiency of photosynthesis so that crop production can increase [20]. The application of silica can make the leaf angle more upright. This can cause the leaves to be more effective in the absorption of sunlight so that the process of photosynthesis can increase and affect the increase in plant biomass and crop 
seed yield [21]. Rice plants that are not given silica can cause the number of dry grains to increase, the grain weight to decrease, the length of panicle to decrease, the number of panicles and the number of grains per panicle will also decrease [22].

\section{Conclusion}

This study shows that the application of N, P, K and Nano Silica fertilizers affect increasing total $\mathrm{N}$ content, $\mathrm{N}$ uptake, and Black Rice (Oryza sativa L. indica) yields on Inceptisols from Jatinangor. The combination of $1 \mathrm{~N}, \mathrm{P}, \mathrm{K}$ (Urea $300 \mathrm{~kg}$ $\mathrm{ha}^{-1}, \mathrm{SP}-3650 \mathrm{~kg} \mathrm{ha}^{-1}$, and $\left.\mathrm{KCl} 50 \mathrm{~kg} \mathrm{ha}^{-1}\right)+1$ Nano Silica $(2$ $\mathrm{mL} / \mathrm{L}$ ) gives the best results on plant $\mathrm{N}$ uptake and Milled Dry Grain yield as much as $82.20 \mathrm{~g} /$ plant or equivalent to $11.18 \mathrm{t}$ $\mathrm{ha}^{-1}$ in Inceptisols from Jatinangor.

\section{Acknowledgements}

The research funding was provided by Soil Chemistry and Plant Nutrition Laboratory, Faculty of Agriculture, Universitas Padjadjaran in 2020.

\section{References}

[1] Purwanto, E. 2010. Benefits of black rice. Universitas Sebelas Maret. Solo.

[2] Pramitasari R. 2014. The antioxidant potential of black rice-based functional drinks (Oryza sativa L. indica) and black soybeans (Glycine $\max$ L. Merr) for the elderly with type 2 diabetes mellitus. Thesis. Universitas Gajah Mada, Yogyakarta.

[3] Kristamtini. 2010. Let's Preserve Local Black Rice. Yogyakarta Agricultural Technology Study Center.

[4] Adhi, R. K. 2017. Black rice: Healthy food ingredients. Binuang Agricultural Research Center.

[5] Indonesian Center for Agricultural Land Resources. 2006. The Soil Physical Properties and Methods of Analysis. Ministry of Agriculture, Bogor.

[6] Sudirja, R., and Hindersah, R. 2007. The concentration of cadmium in agricultural fields of vegetable crops in Lembang Bandung. J. Peng. Will, 3, 6-10.

[7] Hardjowigeno, S. 2015. Soil Science. Akademika Pressindo, Jakarta.

[8] Amrullah, Sopandie, D., and Junaedi, A. 2014. Increased Productivity of Rice Plants (Oryza sativa L.) through The Application of Nano Silica. Food Journal. 23 (1), 17-32.
[9] Suwardi. 2007. Utilization of Zeolites to Improve Soil Properties and Increase Agricultural Production. Proceedings. Workshop on Soil Enhancers Saves Fertilizer in Support of Increased Rice Production. Jakarta.

[10] Rusmanto, B. 2014. Silka Inorganic Biomax. Bogor: PT. BIOTIS AGRINDO.

[11] Rustini, A. Yuniarti, and Y. Machfud. 2018. The application for combining synthetic and liquid fertilizers to improve paddy yield. Faculty of Agriculture, Universitas Padjadjaran. Sains and Technology Research Journal Vol 23 Number 2.

[12] Tampoma, W. P., T. Nurmala, and M. Rachmadi. 2017. Effect of silica dosage on physiological and yield characteristics of local poso rice cultivars (cultivar 36-Super and Tagolu). Journal of cultivation vol 16 (2): 320-325.

[13] Sutedjo, M. M. 2008. Fertilizers and Fertilizing Methods. Rineka Cipta. Jakarta.

[14] Roesmarkam, A. and Yuwono, N. W. 2002. Soil Fertility. Kanisius. Yogyakarta.

[15] Faradiba D. 2016. The Effect of Combination Foliar Silica and NPK Fertilizer on Growth and Yield of Paddy. Thesis. Dept. Land Science and Land Resources, Faperta, IPB. Bogor. 41 pages.

[16] Firmansyah, I and Nani, S. 2013. Effect of N Fertilizer Dosages and Varieties On Soil pH, Soil Total-N, N Uptake, and Yield of Shallots (Allium ascalonicum L.) Varieties on Entisols-Brebes Central Java. J. Hort. 23 (4): 358-364.

[17] Makarim, A. K., E. Suhartatik, and A. Kartohardjono. 2015. Silicon: Important Nutrient in Rice Production Systems. Food Crop Science and Technology. 2 (2): 195-204.

[18] Soplanit, R. and S. Nukuhaly. 2012. The influence of NPK nutrient management on $\mathrm{N}$ availability and rice yield in Waelo Village, Waeapo Subdistrict, Buru District. Journal of Plant Cultivation Vol. 1, No. 1.

[19] Dobermann, A. dan Fairhurst, T. 2000. Nutrient Disorders and Nutrient Management. Tham Sin Chee. 191 p.

[20] Prasetyo, T. B., Y. Syafrimen, and Y. Edri. 2010. The effect of giving coal ash as a source of silica $(\mathrm{Si})$ for the growth and production of rice plants (Oryza sativa L.). Solum 7: 1-6.

[21] Junior, L. A. Z., R. L. F. Fontes, J. C. L. Neves, G. H. Korndorfer, dan V. T. Avila. 2010. Rice grown in nutrient solution with doses of manganese and silicon. Rev. Bras. Cienc. Solo. 34: 1629-1639.

[22] Ma, J. F. dan Takahashi, E. 2002. Soil, Fertilizer and Plant Silicon Research in Japan. Elsevier Science B. V. Amsterdam. 17-39. 